капитале товариществ, обществ с ограниченной (дополнительной) ответственностью и необходимым количеством паев в уставном капитале кооператива.

$$
* * *
$$

1. Артабаева Л.С. Некоторые особенности предприятия как имущественного комплекса // Адвокат. 2007. - № 4. - C. 26-30.

2. Веденин А.А. Сравнительная характеристика договоров купли-продажи предприятия как имущественного комплекса и предприятия как комплекса имущества // Юрист. -2011 . - № 17. - С. 1019.

3. Мурдалов Д.Р. Понятие и признаки договора продажи предприятия // Инновационные технологии в науке и образовании. -2015. - № 1 (1). - С. 373-374.

4. Самигулина А.В. Договор купли-продажи предприятия в российском гражданском праве и иные формы перехода прав на предприятие // Право и экономика. - 2009. - № 4. - С. 28-31.

5. Суевалов М.С. Купля-продажа предприятия как основная форма приобретения бизнеса // Российская юстиция. - 2007. - № 8. - С. 52-55.

\title{
Хлебова В.Ю. \\ Возмещение убытков и взыскание компенсации за нарушение исключительных прав на объекты авторского права: проблемы применения
}

doi: $10.18411 / \mathrm{lj}-31-08-2017-08$

(Россия, Ростов-на-Дону

idsp: 000001:lj-31-08-2017-08

\section{Аннотация}

Статья посвящена проблемам защиты исключительных прав на объекты авторского права. На основе анализа действующего законодательства и судебной практики автором проанализирована целесообразность применения таких способов защиты, как возмещение убытков и взыскание компенсации за нарушение исключительных прав на объекты авторского права и даны практические рекомендации.

Ключевые слова: компенсация, исключительные права, объекты авторского права, интеллектуальная собственность, результаты интеллектуальной деятельности

Возмещение убытков как способ гражданско-правовой защиты прав имеет компенсационный характер. В ст. 15 Гражданского кодекса Российской Федерации (далее ГК РФ) закреплены общие положения возмещения убытков, в том числе и в сфере авторско-правовых отношений. При этом под убытками понимается реальный ущерб, а также неполученные правообладателем доходы в результате правонарушения (упущенная выгода). Лицо, чьи права были нарушены, имеет право требовать возмещения убытков в размере не меньшем того дохода, которое другое лицо получило, нарушив права собственника (абз. 2 п. 2 ст. 15 ГК РФ).

В судебной практике чаще всего убытки в сфере оборота исключительных прав рассматриваются в виде упущенной выгоды. Упущенная выгода может выражаться в неполученном вследствие нарушения соответствующих прав вознаграждении, или в неполученном доходе от самостоятельного коммерческого использования охраняемого объекта. Закон не ограничивает правообладателя в выборе упущенной выгоды, оставляя этот вопрос на усмотрение правообладателя и суда.

Однако законом предусмотрено удовлетворение требований упущенной выгоды при условии доказанности размера доходов нарушителя или размера неполученных правообладателем доходов. Размеры компенсации рассчитываются на основании выявленных фактов нарушения, которые не всегда можно установить в полном объёме (например, оборот контрафактной продукции). Поэтому обоснование размера упущенной выгоды является непростой задачей и правообладатели все чаще требуют взыскания 
компенсации за нарушение исключительных прав. Данный способ защиты вызывает много вопросов, потому что методика исчисления размера компенсации в законодательных и иных нормативных правовых актах Российской Федерации до настоящего времени не выработана.

Компенсация воспринята из англосаксонской системы права, где она именуется статутными убытками. Особая роль судебного прецедента в данном правопорядке приводит к тому, что в аналогичных делах предусмотрен одинаковый размер компенсации. В романо-германских системах действует порядок, основанный на законе, и решение суда не может выйти за рамки закона. В ГК РФ установлены только границы компенсационных выплат. Точный размер компенсации определяет суд, исходя из доказательственной базы, предоставленной сторонами. Это приводит к различиям в отношении взыскания суммы компенсации по сходным делам.

Первоначально арбитражные суды при взыскании компенсации ошибочно руководствовались ст. 333 ГК, то есть, применяли ненадлежащую норму, снижали размер компенсации, фактически необоснованно приравнивая ее к неустойке. После принятия Постановления Пленума Верховного суда и Высшего Арбитражного суда от 26 марта 2009г. №5/29 «О некоторых вопросах, возникших в связи с введением в действие части четвертой Гражданского кодекса Российской Федерации»судебная практика по данной категории дел стала более единообразной.

Законодатель не случайно ввёл механизм компенсации, приближенной к размеру убытков правообладателя, но сложно доказываемых с математической точностью. В абз. 3 п. 3 ст. 1252 ГК законодатель устанавливает порядок исчисления размера компенсации за каждый случай неправомерного использования результата интеллектуальной деятельности или средства индивидуализации. При этом в абз. 2 п. 3 ст. 1252 ГК законодатель обязывает суды действовать на основе принципов разумности и справедливости при вынесении решения.

Суд при определении суммы компенсации не может выйти за установленные пределы, за исключением случаев, когда неправомерными действиями нарушены права на несколько результатов интеллектуальной деятельности, принадлежащих одному правообладателю. Кроме того, руководствуясь п. 3 ст. 1252 ГК и п. 43.3 Постановления Пленума ВС и ВАС от 26 марта 2009г. № 5/29 «О некоторых вопросах, возникших в связи с введением в действие части четвертой Гражданского кодекса Российской Федерации», суд назначает сумму к выплате нарушителем, обосновывая ее и имея возможность занижать сумму компенсации, заявленную истцом.

Размер компенсации может исчисляться, исходя из двойного размера стоимости контрафактных экземпляров авторских произведений (п. 2 ст. 1301 ГК РФ), что порой многократно превышает размер причинённых правообладателю убытков. Доходыиндивидуальных предпринимателей, нарушивших исключительные права, не покрывают сумму компенсации, которая в данном случае, может расцениватьсякак штраф. Гражданское законодательство не предусматривает карательных мер. И суд, рассматривая дело, высчитывает количество экземпляров, или берет за основу размер вознаграждения, обусловленный договором, должен учитывать эти факторы, воплощая принципы разумности и справедливости и Постановление Конституционного Суда РФ от 13. 12.2016 № 28-П.

В Постановлении Пленума ВС и ВАС от 26 марта 2009г. № 5/29 «О некоторых вопросах, возникших в связи с введением в действие части четвертой Гражданского кодекса Российской Федерации» в п. 43.3 указаны условия определения размера компенсации: характер допущенного нарушения, срок незаконного использования результатов интеллектуальной деятельности, степень вины нарушителя, наличие ранее совершенных лицом нарушений исключительных прав данного правообладателя, вероятные убытки правообладателя, не учитывая последствия применения данной меры 
ответственности относительно дальнейшей деятельности нарушителя. Однако данное Постановление дает возможность судам исходить из одних критериев, создавая единую практику.

Таким образом общее правило состоит в том что если одним действием наршены права на несколько объектов авторского права размер компенсации определяется судом за каждый неправомерно используемый результат или средствоКомпенсация, исчисленная с учетом конкретных обстоятельств дела в минимально допустимом размере, исключает возможность применения к нарушителю прав на результаты интеллектуальной деятельности или средства индивидуализации санкцииявляющейся явно несправедливой и несоразмерной допущенному нарушению или многократно превышающей размер причиненных правообладателю убытков, и тем самым исключает нарушение баланса их прав и законных интересов.

Подытоживая вышеизложенное отметим, что взыскание компенсации является альтернативой возмещению убытков, но с практической точки зрения данный способ защиты целесообразно использовать в случаях, когдатрудно доказать объем потерь от правонарушений в области защиты исключительных авторских и смежных прав. Отсутствие установленного порядка исчисления компенсации вызывает много вопросов у правоприменителей и именно суд должен объективно и всесторонне оценить все имеющиеся по каждому конкретному делу обстоятельства и принять законное и справедливое решение.

$$
\text { *** }
$$

1. Гражданский кодекс Российской Федерации (часть четвертая) от 18 декабря 2006г. № 230-Ф3 (в актуальной редакции) // Собрание законодательства РФ. 2006. №52, ч.1. Ст.5496.

2. Постановление Пленума Верховного суда и Высшего Арбитражного суда «О некоторых вопросах, возникших в связи с введением в действие части четвертой Гражданского кодекса Российской Федерации». 26 марта 2009. № 5/29 //Неофиц. ист.: Справочно-правовая система «Гарант»: дата обращения 21.06.2017.

3. Постановление Судапоинтеллектуальнымправамот 13 апреля 2015г.// Неофиц. ист.: Справочноправовая система «Консультант»:датаобращения 12.08.2017г.

4. Постановление Конституционного Суда РФ от 13. 12.2016 № 28-П// Неофиц. ист.: Справочно-правовая система «Консультант»:датаобращения 10.08.2017г.

5. Шатковская Т.В. Интеллектуальнаясобственность в правеРоссийскойФедерации и Европейскогосоюза: проблемы и перспективыинтеграции. В сборнике: Правоваязащитаинтеллектуальнойсобственности: проблемытеории и практики. М., 2017. С. 290-295.

6. Шатковская Т.В. Правовые проблемы государственного регулирования инновационной деятельности и инфраструктуры в Российской Федерации // Наука и образование: хозяйство и экономика; предпринимательство; право и управление. 2016. № 5 (72). С. 4043. 